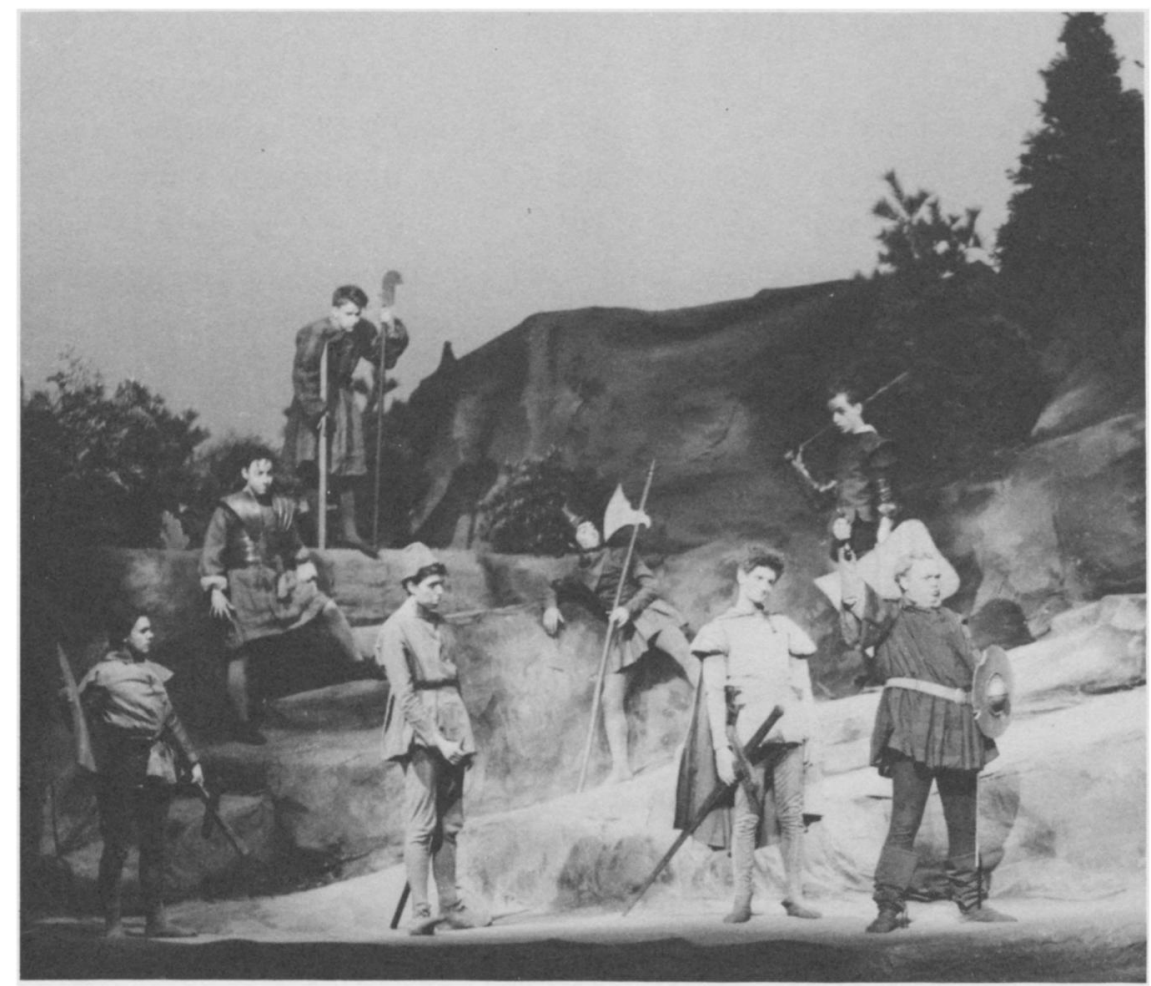

Tennessee Williams (second from left with feet spread) had a minor role in the April 1938 production of Shakespeare's Henry IV, Part 1 at The University of Iowa. Photo: UI Theatres. 


\section{Experimental Theatre Seminar; or the Basic Training of Tennessee Williams: A Memoir - Thomas D. Pawley}

THE SUBTITLE of this essay is not entirely accurate. What I will be describing is my own experience as a student in Speech 211-212 during the 1937-38 academic year at the State University of Iowa, an experience which I believe parallels that of the other student playwrights, among them Tennessee Williams. To paraphrase the lines of Tom in The Glass Menagerie, this effort is memory, told from the perspective of five decades. I hope it will add something to the understanding of the maturation of a genius.

I entered the Department of Speech and Dramatic Art in September 1937 with an A.B. in English, having only recently turned twenty. Although I was a graduate student, I had not written a play or taken a single course in theatre. Fortunately, this did not prove to be a barrier to my admission to the Graduate College. As an English major, I had of course read numerous dramas especially those of Shakespeare and been a very active participant in the Virginia State College Theatre Guild. I had also written poetry, essays, news articles, and a short story. Although I had had no formal training, a summer in New York convinced me that I should pursue a career in the theatre either as a writer or actor.

When I appeared for registration Professor E. C. Mabie questioned me closely concerning my background. ${ }^{1} \mathrm{~A}$ singluar if not eccentric man, he along with others on the Iowa faculty had pioneered the concept of creative writing projects in lieu of the traditional master's thesis and doctoral dissertation. It was this along with Iowa's liberal reputation toward blacks that caused me to seek admission. As a result of our conference I found myself with the following schedule:

Modern Continental Drama 3 s.h.

Advanced Acting 3 s.h.

Experimental Theatre Seminar 2 s.h.

Speech Improvement 2 s.h.

Stagecraft 3 s.h.

Thesis Seminar 2 s.h. 
With the exception of the course in Speech Improvement, my schedule was not unlike that of the other theatre students. I learned later that as a potential playwright I was "high caste." Thus, I was permitted to substitute Speech Improvement for the all pervasive Voice and Phonetics which everyone was required to take because it conflicted with Experimental Seminar. At the time I thought it was because of my Virginia accent. I had sought to enroll in the basic course in acting but Professor Mabie assigned me to the advanced class after learning the roles I had performed. Likewise I had naively sought to enroll in the beginning course in playwriting offered by the Department of English (not knowing of the intense rivalry between the two areas) since no such course was was scheduled that semester in Dramatic Art. However, when he discovered my interest in writing, Mr. Mabie placed me in Speech 211 Experimental Theatre (or Experimental Dramatic Production) with Norman Felton, Hayes Newby, Glen Low, Bill Corington, Tom Williams, and others, all seniors or graduate students majoring in theatre. ${ }^{2}$

I was not happy at having been enrolled in a course whose title did not suggest that I would be taught how to write plays. Since none of the other students complained, I assumed that they had all had prior training in playwriting. Later I learned that most of the class had had little or no formal training. Even Williams, a senior who had transferred from the University of Missouri where he had majored or attempted to major in Journalism, had taken courses in narrative and expository writing but not playwriting. However, I have since discovered that he was more advanced than the rest of us because he had written several one-acts, a couple of long plays and had had two plays produced. He also wrote at some point during the 1937-38 year his third long play entitled Spring Storm. ${ }^{3}$ My guess is that it was completed during the summer session.

Williams, although shy, reticent, and taciturn (I also felt he was unkempt), was always cordial to me. During one of our infrequent conversations he said, "You've got something to write about -We don't." I was genuinely surprised at his apparent sympathy for Negroes and also grateful for this bit of encouragement from one whose writing I had grown to admire. That he was indeed encouraging me was confirmed nearly fifty years later by his biographer Lyle Leverich in these words: "Since Tom's Mississippi accent was always pronounced, to say the least, I wonder that you were not leery of him on that account alone. Did he put you at ease? I 
know he admired your writing at the time because in a letter to Willard Holland (director of the St. Louis Mummers) he tells of the "living newspaper" series and, because of his Southern accent, acting "the part of chairman at an African Methodist Episcopal Church Conference, condemning Senator Black's appointment to the [Supreme] Court. Incidentally the play was written by a Negro who shows real talent." 4 I have often wondered in retrospect why in view of his apparent sympathy for blacks and his Mississippi/Missouri background that black characters are few and far between in his writings. ${ }^{5}$ When I first met him he told me he was from St. Louis. Had I known he was a native Mississippian, I wouldn't have been so friendly. In those days, having just emigrated from Virginia, I was leery of white people from the deep South, especially Mississippi, which had an unsavory reputation in racial matters. As it was, my contacts with him, as well as with other classmates, were confined to the classroom. Even in liberal Iowa, extra class social contacts between blacks and whites were taboo.

At the first meeting of the class in an ancient, red brick building on the Pentacrest, we were told by Dr. E. P. Conkle that we were going to write short "living newspaper sketches," that is to say we were going to dramatize news events on a weekly basis in the manner of the Federal Theatre's Living Newspaper. ${ }^{6}$ I cannot speak for the others but I was only vaguely familiar with the genre. We were also informed that each week several of the sketches would be selected for production by students in the directing and acting classes. The prospect of immediate production served as a catalyst for me in overcoming my fears and meeting the weekly deadlines.

We were given a reading list which included George P. Baker's Dramatic Technique, John Howard Lawson's Theory and Technique of Playwriting, William Archer's Playmaking, and Allardyce Nicoll's European Theories of the Drama. However, we did very little discussing of playwriting theory. Instead we spent most of our time reading and discussing our sketches. We were supposed to meet twice a week but we were frequently dismissed. Most of our time was spent in writing and attending rehearsals. ${ }^{7}$ I was surprised (and delighted) when my initial effort, a sketch entitled $K u$ $K l u x$, was selected for production since it was highly critical of the appointment of Alabama Senator Hugo Black, an ex-klansman, to the Supreme Court. It was in this play that Williams played the role of a black minister. Much of the news of the day involved social and political issues 
brought on by the Great Depression, President Roosevelt's social programs, and Hitler's warlike activities. As a result, many of our sketches had a strong social or political orientation. One of Williams' sketches, the only one I can remember in fact, was an exception. Given a Victorian setting, it was far removed from the contemporary scene. I was duly impressed and congratulated him following the production. The conversation went something like this:

"I like your sketch very much."

"You know what it was, don't you?"

"No."

"Browning's 'My Last Duchess.',

"Oh. ( I had not read Browining) But it was beautifully written."

"The lines were Browning's."

"I still think it was beautiful."

"Thanks."

Our conversations were always like this, brief and laconic.

The following are sketches which I submitted:

The Fate of the Limit, based upon an article about a lost fishing boat in the Arctic.

Shackled, about a wife who seeks annulment of a marriage to a drunken husband.

Mother, in which a youth who is dominated by his dead Mother's wish that be become an artist does not marry the girl he loves.

Sideshow, in which an attempted murder is treated humorously.

One Man Strike, a treatise on college football.

Sit-Down, about a labor strike in which workers take over a factory.

The Spirit of Xmas, in which a cripple and would-be-murderer spares his victim. (My second production)

Sports Continuity, a narrative for I don't know what.

My recollection is that the sketches of the other student playwrights were similar to those. However, keeping in mind the Browning sketch, I am not sure that Williams' were always based upon his newspaper reading. During the latter part of the semester we were divided into four writing teams for the purpose of developing longer sketches. Each team had a sponsor, one of three Ph.D. candidates in playwriting and Dr. Con- 
kle (who was the first Ph.D. in playwriting at Iowa) and a directing staff, composed for the most part of graduate students in theatre. (See Exhibit A) This apparently occurred in November because three of the scripts were scheduled for production in January, the fourth for "early next semester." I was assigned to the "Government Conservation" group, Williams to "Socialized Medicine." I do not recall whether any of the four scripts were actually written.

What was written and produced by a group that did not include Williams was Dust Bowl, a full length living newspaper. (See Exhibit B) This was probably an outgrowth of the "Government Conservation" project since the writers included all four members of that team together with two writers from the "Drama of Iowa Farmers" project. This being the case, I suspect that Dust Bowl was a synthesis of these two projects, the other two having failed to materialize or proved to be unsatisfactory. The choice of subjects reflected Mr. Mabie's interest in regionalism. The work of painters Thomas Hart Benton, John Steuart Curry and Grant Wood, who was then a teacher at the University, was widely discussed and admired. Playwrights Lynn Riggs and Paul Green were frequently produced. Riggs' plays such as Cherokee Night and Green Grow the Lilacs drew upon his Oklahoma background. The latter play ultimately became the musical Oklahoma. Paul Green, a North Carolinian, exploited the folkways of the Southern Negro. His play of racial conflict, In Abraham's Bosom, won the Pulitzer Prize for drama in 1926. Consequently, we were encouraged from the beginning to explore our regional origins, in my case the American Negro. ${ }^{8}$

E. C. Mabie had been or was a Regional Director of the Federal Theatre serving under National Director Hallie Flanagan Davis. It had produced the highly successful full length production One Third of a Nation, as well as others, such as Triple A Plowed Under, Injunction Granted, and Power. Having seen at first hand the effectiveness of the form, Mabie was determined to dramatize the conditions of the farmers in the Midwest and to do it in the manner of the Living Newspaper. This more than anything else was the reason for the writing and production of Dust Bowl.

That we did some outside reading during the first semester is apparent from my notes. Also I am sure that we were warned that the final examination (See Exhibit C) would include questions on playwriting theory. My folder includes notes from the following: 
From An Introduction to Dramatic Theory by Allardyce Nicoll (a chapter) Tragedy and Comedy

A scenic analysis of Power (Living Newspaper Script)

A scenic analysis of Triple A Plowed Under (Living Newspaper Script)

From Theory and Technique of Playwriting by John Howard Lawson

Nature of action and conflict

Dialogue. (No source noted.)

From Dramatic Technique by G. P. Baker

Characterization

From Playmaking by William Archer

Choice of Theme

Dramatic and Undramatic

The Routine of composition

Dramatic Personae

The Point of Attack - Shakespeare and Ibsen

Exposition

The First Act

My apparent predilection for Archer rather than the other authors probably resulted from my admiration of Ibsen whose plays he had edited and translated.

The course ended with a final examination of seven questions (see Exhibit C) which drew heavily on our classroom experience. Only two focused on outside reading. Most probed our experiences both in and outside the classroom. As a beginner I had only the classroom sketches to my credit. In retrospect I now realize that Questions II-V were designed for persons like Williams who had written fairly extensively. But apparently my answers were satisfactory to both Professor Mabie (who I recall also read them) and Dr. Conkle since I was awarded a grade of B. In this connection it is alleged that many years later after Williams had achieved international renown that Professor Mabie examined his academic record at Iowa and was pleased to discover that the only B's he'd earned were in the Playwriting Seminar and Shakespeare. I cannot vouch for the story's authenticity. It was a very practical examination reflecting Professor Mabie's philosophy of learning by doing.

In retrospect I can state that this first semester was a valuable experience for me as I assume it was for Williams. We had to turn in scripts regularly 
so there was not a great deal of "pencil tapping." But most importantly we were able to see the results of our efforts on stage.

The second semester was less exciting and much more conventional. My recollection is that we were all required to complete a one-act play which we read to the class. Mine was entitled Sunset. In contrast to the first semester, we spent a great deal of time discussing playwriting theory. My notes of February 23, 1938 were entitled "Principles for Standards of Judgment." Six principles/standards are listed. The notes for March 8 dealt with "Characterization." We apparently were also assigned the reading of a biography or autobiography. I chose Toussaint L' Ouverture, the black liberator of Haiti, who was subsequently captured by the French and died in prison, thinking that I would write a play about him. The lecture of March 15 is titled "The Treatment of Mary of Scotland" with the approaches of Schiller, Bjornson, and Anderson being contrasted. We were then assigned the reading of Chapters 1 and 2 from Baker (See above) which was probably a reassignment from the first semester. George Pierce Baker, the founder of the English 47 Workshop at Harvard, was one of Professor Mabie's friends and visited the campus on at least one occasion (I believe) while I was a student. His book was required reading.

A lecture on the "Universal Qualities of Playwriting" followed and one on Polti's "The Thirty Six Dramatic Situations." The final page of notes is entitled "Questions Concerned in Playwriting." These I assume were given in preparation for an examination as well as to stimulate our own thinking. The questions reflect E. C. Mabie's philosophy. Here are three examples:

1. Is it necessary for a dramatist to know physical theatre?

2. Why do the great critics fail to write drama?

3. How is imagination destroyed by studying method?

An assignment sheet for March reveals a heavy emphasis on the "biographical" play which treats climactic events in the lives of famous personages. ${ }^{9}$ This apparently had little immediate influence on Williams unless the play "Spring Storm" was autobiographical. It obviously influenced the output of others in the class because I recall Norman Felton's Rusty Gun, a play about Billy the Kid, a play on Leonardo da Vinci by Glenn Low and my own Crispus Attucks, on the black martyr of the "Boston Massacre," all 
of which were ultimately produced. What if any influence this had on Williams' later autobiographical plays or the strongly autobiographical elements in certain plays I can only speculate. It is alleged that an early version of The Glass Menagerie was written that year. This may have occurred during the summer when I was not present.

The final examination for the second semester (See Exhibit D) tested our understanding of Baker and the historical play and probed our own personal philosophy. It must have left me with a feeling of euphoria since I secured the autographs on it of Dr. Conkle and three of my classmates including Williams.

In summary Speech 211-212 as taught during the 1937-38 academic year was a course which combined the theoretical and the practical, stressing the necessity for the playwright to examine closely his own background and to develop his own philosophy of writing. It gave beginning playwrights an opportunity to see their work produced and to have it evaluated. By requiring the writing of sketches based upon contemporary events as well as the study of the biographical play, it broadened the scope of our quest for dramatic subject matter.

These were values which to some degree may have been shared by Tennessee Williams.

\section{Notes}

1. Edward Charles Mabie, A.B., M.A. Dartmouth, was acting head of the Department of Speech and Dramatic Art at The University of Iowa from 1923-25, and head from 1925 until his death in 1956. Although he came to Iowa to teach debating, Professor Merry, who was then the Department Head, decided to put him in charge of the theatre program. In a letter to the late Dr. H. C. Harshbarger he explained it this way: "As a teacher of drama I was a flop. I could handle debating if someone took theatre from me. Ed was a dramatic personality with an unmitigated temper. So I turned him loose; you know the results. He was a creative genius." H. Clay Harshbarger, "Some Highlights of the Department of Speech and Dramatic Art," Iowa City, 1976, p. 13.

2. Dr. H. Clay Harshbarger states, "One interesting fact: during the Mabie years playwriting was never listed as a course. It was taught under 
the title of Experimental Theatre at both graduate and undergraduate levels." H. Clay Harshbarger, "Highlights," 24.

3. Signi Lenea Falk, Tennessee Williams (New York, 1961) pp. 15-16.

4. Letter from Lyle Leverich, February 5, 1986.

5. In his Memoirs he describes his friendship with Lomax and his "beautiful Negro girlfriend." Mississippi and Missouri were rigidly segregated by law until the late 1950s. In a critical essay, "The Black Experience in the Theatre of Tennessee Williams," presented at the Black Theatre Conference at the University of Massachusetts on May 1, 1987, I attempt to answer this question.

6. The Living Newspaper was essentially documentary drama in cinematic form. It addressed a current social, political, or economic problem, as for example in Triple $A$ Plowed Under, which attacked the Supreme Court's invalidation of the Agriculture Adjustment Act, Power, which concerned the need for rural electrification and the best remembered of all, One Third of a Nation, which took its title from Franklin Roosevelt's assertion that one third of the nation were ill fed and ill housed.

7. Professor Mabie insisted that playwrights have the leisure time to write. Consequently during my years at Iowa my schedule was loaded with Seminars and Independent Study courses.

8. Dr. E. P. Conkle typified this interest. His plays focused on his native Nebraska. Two Hundred Were Chosen, produced by the Federal Theatre, depicted an effort of Midwesterners to settle in Alaska.

9. Dr. Conkle's biographical play about Abraham Lincoln, Prologue to Glory, had been produced in New York by the Federal Theatre. 


\section{EXHIBIT A \\ Living NewsPaper Assignments}

\section{LONG SKETCHES}

I. Government Conservation

Sponsor: Robert Whitehand

Writing Staff: Thomas Pawley, Marion Harris, Bermice Rogers, Lucille Ruby

Directing Staff: Jack Leland, Rodney Stewart, Glenn Low

Script ready for the Director by December 9

Production January 6

II. Federal Housing

Sponsor: Marcus Bach

Writing Staff: Norman Felton, Leo Dahm, Jannes Savery, Charles Jones

Directing Staff: William Heiman, Peter Marroney, Rachel Bastian

Script ready for the Director by December 14

Production January 13

III. Socialized Medicine

Sponsor: E. P. Conkle

Writing Staff: Thomas Williams, Hayes Newby, Derelle Atkinson, Eduardo Escalona

Directing Staff: Stefan Straka, Charles Jones, Max Ellis

Script ready for the Director by December 14

Production January 20

IV. Drama of Iowa Farmers

Sponsor: Warren Lee

Writing Staff: William Corington, James Fox, Glenn Low, Alberta

Kelly

Directing Staff: Don Clark, John Felton, Max McCullough

Script ready by January 13

Production early next Semester 


\section{EXHIBIT B}

\section{The Living Newspaper Presents}

\section{DUST BOWL}

(Written by members of Speech 211: Lucille Ruby, Bernice Rogers, Tom Pawley, Glenn Low, Marion Harris, James Fox.)

Directed by Jack Leland

Continuity read by

Max McCullough

Old Jake Campbell Leonard Marshall

Molly Campbell .Laurene Dahl

Mrs. Campbell Marion Whinnery

Mrs. Kincaid LaVerna Goodman Joe Campbell Hy Andich Jack Campbell Bill Roberts Nancy Helene Winterson

Lem . . .Pix Miller

Dave Walter Fleischmann

Blaine Jay Cline

Foster Leonard Marshall

Hilton .Joe Becker

Snead Walter Fleischmann Young Jake Campbell $\ldots \ldots \ldots \ldots \ldots \ldots \ldots \ldots$ Tony Paciotti Nelson Tom Nelson

Margaret Hilton . Margaret Wheeler Ellison Walter Fleischmann Marshall Leonard Marshall

Macready Jay Cine

Davis Hy Andich Johnson Rodney Erickson

Benton Hobart Sorenson

Jones Rodney Erickson Christianson Walter Fleischmann Coffman Rodney Erickson

Stage Manager Glenn Low

Properties and "Effects" ..... . Rodney Stewart

Lighting .... John Felton and Peter Marroney

Costumes Madia Dryden 


\section{EXHIBIT C \\ Examination, SPEEch 2II}

I. A. Make a bibliography of all the books you have read on the subject of playwriting.

B. Analyze one of these books as to its contents, point of view, etc.

C. Discuss its value as a guide in playwriting.

II. If you were writing a book on Playwriting, what would you say in the chapter on "How to Create Characters in a Play"?

III. Do the same for a chapter on "How to Write Dialogue."

IV. Discuss plot in the drama. What are the characteristics of a good plot?

V. If you were given an Idea suitable for a play, how would you set out to write the play? Describe the process in detail, step by step, from beginning to end.

VI. Make a set of "Instructions for Writing Living Newspaper Sketches" for someone who is about to begin writing them. Base your ideas upon your own experiences in connection with our own Living Newspaper set-up and upon your reading of the Federal Theatre's Living Newspapers. Present your ideas from the point of view of the playwright.

VII. Describe and discuss Power.

\section{EXHIBIT D \\ EXAMINATION, SPEECH $2 \mathrm{I} 2$}

I.

Discuss characterization and dialogue in the drama basing your essay on Baker's Technique.

II.

Discuss the treatment of historical materials in the drama.

III.

Given the following statement, how would you go about treating it dramatically:

"He believed all diseases could be treated by salt."

IV.

Discuss your interests in writing plays, what you seek for the future in playwriting, your philosophy of writing.

May 27, 1938 